\title{
Natural dyeing of silk fabric with Polygonum cuspidatum
}

\author{
Sangyool $\mathrm{Kim}^{+}$ \\ Dept. of Clothing \& Textiles, Mokpo National University, Korea/ \\ Human Ecology Research Institute, Mokpo National University, Korea \\ 호장근을 이용한 견직물의 천연염색 \\ 김 상 률 \\ 목포대학교 의류학과/목포대학교 생활과학연구소
}

\begin{abstract}
In this study, the dyeing of silk fabric with Polygonum cuspidatum extracts was investigated. The contents of this study are as follows. First, the proper dyeing conditions were investigated by measuring the dye uptake (K/S value) that depended on the dyeing conditions when silk fabric was dyed with Polygonum cuspidatum extract. Second, the brightness $(\mathrm{L})$, hue, and chroma differences that appear after mordanting with $\mathrm{Al}, \mathrm{Cu}$ and $\mathrm{Fe}$ were investigated by measuring the CIELAB and Munsell values. And third, the colorfastness and antibacterial property were measured. When the silk fabric was dyed with Polygonum cuspidatum extract, the proper dyeing conditions were a colorant concentration of $90 \% \mathrm{v} / \mathrm{v}$, a dyeing of time 100 minutes, a dyeing temperature of $70^{\circ} \mathrm{C}$, and a dyeing of $\mathrm{pH}$ 3. In mordanting methods, the dyeabilities of post-mordanting were higher than those of premordanting. The hue value displayed yellow $(\mathrm{Y})$ and yellow-red (YR) in cases of pre and post mordanting. The $\mathrm{C}$ value decreased by the mordanting of Polygonum cuspidatum extracts. Generally the colorfastness of mordanted fabrics was improved by mordanting. The dyed fabrics showed a $90.6 \%$ of Staphylococcus aureus reduction rate, and the dyed and mordanted fabrics showed $97.1 \%$ bacteria reduction rate. The dyed and mordanted fabrics showed above $90.5 \%$ Klebsiella pneumoniae reduction rate, and $\mathrm{Cu}$ mordant revealed the most effective bacterial reduction.
\end{abstract}

Keywords: natural dyeing(천연염색), colorfastness(염색견뢰도), mordanting(매염), Polygonum cuspidatum(호장 근), bacterial reduction(균감소)

\section{Introduction}

자연에 존재하는 동물, 식물 및 광물에서 색소를 취득하여 염색하는 것을 의미하는 천연염색은 오래 전부터 우리나라에서도 이용되어 왔다. 천연염색은 다양한 색상 발현이 어렵고, 또한 염색방법이 복잡
하여 산업화, 대중화에 어려움이 많았으며, 염색공 정의 간편성, 염료 보관 및 구입의 용이성을 구비한 합성염료에 비해 사용이 쇠퇴되어 왔다.

그러나 합성염료와 달리 감성적이며 미려한 색을 나타낼 수 있으며, 인체에 해가 없고, 환경오염 또한 유발하지 않는 천연염료는 친환경 염색법 및 항균

Received 15 July 2015, revised 2 September 2015, accepted 3 September 2015.

본 논문(저서)은 2013학년도 목포대학교 교내연구비 지원에 의하여 연구되었음.

'Corresponding author (sykim@mokpo.ac.kr) 
성, 소취성, 항 알레르기성 등의 특성을 부여할 수 있어 최근 많은 관심이 증가하고 있다(Choi \& Jung, 1997; Han, 2000; Choi \& Cho, 2001). 천연염색은 전 통적인 염재들을 중심으로 주로 연구가 진행되어 왔으나, 라벤다(Park, 2006), 참소리쟁이(Son \& Shin, 2006), 까마중(Park, 2007), 감초(Lee \& Jang, 2010), 벚나무(Yi, Yoo, Han, \& Lee, 2010), 감국(Hong, Chu, $\&$ Lee, 2010) 등 최근에는 새로운 염색재료를 응용 하고자 하는 연구들이 보고되고 있다.

호장은 마디풀과에 속하는 다년생 식물로, 우리 나라 전국 각 지역에 자생하며, 예부터 민간에서 이 뇨, 요도염, 방광염 등의 치료약으로 생약으로 호장 (Polygonum cuspidatum Sied. et Zucc.)과 그 근녹식 물의 근경을 호장(Reynoutriae rhizoma)으로 공용하 고 있다(Lee, 1980; Kim, 1996). 한국에 분포되어 있 는 호장류로는 호장(Polygonum cuspidatum Sied. et Zucc.), 왕호장(Polygonum sachalinense Fr. Schm.) 및 둥근잎호장(Polygonum ellipticum Migo) 등 3종 류가 있다.

호장근의 성분은 oxyanthraquinone 유도체인 emodin, polygonin(=emodin 6-glucoside), emodinmonomethylether, physcion(=emodin 7-methyl ether=lichen chrysophanol), chrysophanol, rheochrysin, polydatin, resveratol, cuspidatin 및 그 배당체이며(Ryuk, 1997), 〈Fig. 1〉 은 호장근의 화학구조식을 나타낸 것이다(Kim \& Choi, 2001a).

호장근에 대한 연구는 주로 의학 및 약학 분야에 서 활발하며, 호장근 추출물의 항산화효능(Hsu, Chan, $\&$ Chang, 2007), nitric oxide 생성억제 및 COX-2 활 성억제(Kim et al., 2007), 간염바이러스에 대한 항바 이러스 효능 및 Streptococcus mutans 등에 대한 항 균효과(Chang et al., 2005) 등에 대한 보고 및 그 외 의 분야로 피부미용에 관한 보고(Jung, Roh, \& Oh,

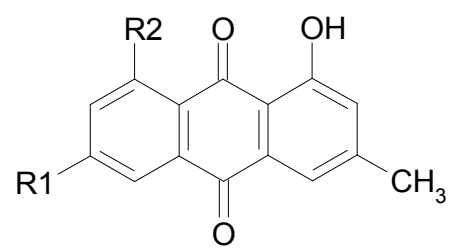

〈Fig. 1〉 Structure of Polygonum cuspidatum
2009) 및 식품분야에 대한 보고(Kim, Kim, Yoo, \& Shin, 2004)가 있었다. 한편, 호장근을 이용한 천연염 색에 관한 연구는 그다지 활발하지 않으나, Kim and Choi(2001a) 등은 견직물 및 나일론직물에 대한 염 색성에 대한 연구에서 $\mathrm{Fe}$ 매염시 견직물의 세탁견 뢰도가 향상되고, 견직물에 비해 나일론직물의 내세 탁성이 더욱 향상되었다고 보고하였다(Kim \& Choi, 2001a). 또한 염색 시 매염제의 종류, 매염방법 등에 따른 광퇴색 거동 및 내일광성에 대한 보고에서는 $\mathrm{Fe}$ 매염 시 매염방법에 무관하게 가장 우수한 내일광 성을 보인다고 보고하였다(Kim, Choi \& Cho, 2002). 한편, 호장근 추출액의 추출용매, 금속이온 첨가 등에 따른 분광학적 거동에 관한 연구(Kim \& Choi, 2001b) 에서는 메탄올 추출 시 가장 높은 흡광도를 나타내 었으며, 금속이온 첨가에 의해 전체적으로 흡광도 값 은 낮아지고, $\mathrm{pH}$ 가 알칼리 영역에서는 광에 매우 불 안정함을 알 수 있었다고 보고하였다. Kim and Choi (2001b) 등의 연구는 호장근 추출색소의 분광 광학 적 특성에 대한 정보를 충실하게 보여주고, 내일광 성, 내세탁성에 대한 결과를 도출하였으나, 일광견 뢰도, 드라이클리닝견뢰도 및 내세탁성을 표면색의 변화, $\mathrm{K} / \mathrm{S}$ 및 색차로 판단하여 실제 사용에서의 판 단기준을 명확화하기에는 조금 아쉬웠다. 따라서 본 연구에서는 Kim and Choi(2001a) 등의 연구에서 행 하지 않은 염색견뢰도 판단에 땀견뢰도 및 마찰견 뢰도를 추가하여 5 항목의 견뢰도를 측정하고, 표준 회색 색표에 의한 등급판정을 하고, 색소농도에 따 른 견직물의 염색성 및 항균성을 측정하여 천연염 료로서의 호장근의 사용 가능성을 더욱 면밀하게 판 단하고자 한다.

본 연구에서는 호장근 추출색소를 이용하여 견직 물에 염색 시, 염색조건에 따른 염색성 변화, 매염에 따른 염착량과 표면색 변화, 염색견뢰도, 항균성 등 을 평가하여, 웰빙 패션소재 제조에의 천연염료로서 호장근의 적용 가능성을 평가하고, 최적조건을 확립 하고자 하였다.

\section{Experimental}

\section{Materials}

〈Table 1〉과 같은 특성을 나타내는 KS K 0905의 
$\langle$ Table 1〉 Characteristics of fabric

\begin{tabular}{c|c|c|c|c}
\hline Weave & $\begin{array}{c}\text { Fabric counts } \\
(5 \mathrm{~cm} \times 5 \mathrm{~cm})\end{array}$ & $\begin{array}{c}\text { Weight } \\
\left(\mathrm{g} / \mathrm{m}^{2}\right)\end{array}$ & $\begin{array}{c}\text { Thickness } \\
(\mathrm{mm})\end{array}$ & $\begin{array}{c}\text { Fiber } \\
\text { composition }\end{array}$ \\
\hline Plain & $276 \times 192$ & $25 \pm 1$ & 0.16 & Cotton $100 \%$ \\
\hline
\end{tabular}

견섬유 백포를 한국의류시험원에서 구입하여 시험 포로 사용하였다.

호장근(한국산)은 시장에서 구입한 것을 분쇄한 후 사용하였으며, 매염제인 $\mathrm{AlK}\left(\mathrm{SO}_{4}\right)_{2} \cdot 12 \mathrm{H}_{2} \mathrm{O}, \mathrm{FeSO}_{4}$. $7 \mathrm{H}_{2} \mathrm{O}, \mathrm{CuSO}_{4} \cdot 5 \mathrm{H}_{2} \mathrm{O}$ 및 기타 시약 등은 1 급인 것을 사용하였다.

\section{Preparation of colorant}

$100 \mathrm{~mL}$ 의 증류수에 호장근 $1 \mathrm{~g}$ 를 가하여 3 구 플 라스크에 넣고, 냉각기, 교반기와 온도계를 설치한 다음, $100^{\circ} \mathrm{C}$ 에서 120 분간 추출한 후 여과하여 이를 색소원액으로 염색 등에 사용하였다.

\section{Dyeing methods}

호장근 추출 색소액을 이용, 염색기로는 IR 타입 (Daelim Starlet Engineering, Model DL-6001)을 사 용하여, $1: 100$ 의 욕비, $10 ~ 100 \% \mathrm{v} / \mathrm{v}$ 의 색소농도, $30 \sim 90^{\circ} \mathrm{C}$ 의 염색온도, $20 \sim 120$ 분의 염색시간, $3 \sim 11$ 의 $\mathrm{pH}$ 로 변화시키면서 염색하였으며, 염색성 $(\mathrm{K} / \mathrm{S})$ 을 비 교 분석하여 각종 염색조건의 영향을 고찰하였다.

\section{Mordanting methods}

$\mathrm{Al}, \mathrm{Cu}, \mathrm{Fe}$ 등을 매염제로 사용, $40^{\circ} \mathrm{C}$ 에서 20 분간 선매염 및 후매염하고, $70^{\circ} \mathrm{C}$ 에서 100 분간 염색을 실 시하였으며, 매염제 농도(1 5\% o.w.f.) 및 매염방법 에 따른 염색성을 비교 고찰하였으며, 매염에 따른 표면색의 변화는 색차계(Color System Co. Model JX 777)를 이용 비교 고찰하였다.

\section{Measurement of color characteristic}

색차계를 사용하여 표면반사율을 $10 \mathrm{~nm}$ 간격으로 400에서 $700 \mathrm{~nm}$ 범위에서 측정한 후 Kubelka-Munk 식에 의해 염색성 $(\mathrm{K} / \mathrm{S}$ 값 $)$ 을 산정하였다.

$\mathrm{K} / \mathrm{S}=(1-\mathrm{R})^{2} / 2 \mathrm{R}$
여기서 R: 표면반사율

$\mathrm{K}$ : 흡광계수

$\mathrm{S}$ : 산란 계수

한편, $\mathrm{CIE}$ 에서 제정한 색차식에 의하여 $\mathrm{L}^{*}, \mathrm{a}^{*}, \mathrm{~b}^{*}$ 값을 측정하고, $\mathrm{H} \mathrm{V/C}$ 는 Munsell 표색계 변환법에 따라 구하였다.

\section{Measurement of fastness}

Launder-o-meter를 사용하여 세탁견뢰도는 $\mathrm{KS} \mathrm{K}$ ISO 105 C06:2007 A2S법으로, Crock-meter를 사용하 여 마찰견뢰도는 KS K 0650법으로, AATCC perspiration tester를 이용하여 땀견뢰도는 $\mathrm{KS} \mathrm{K} \mathrm{0715법으로,}$ Launder-o-meter를 사용하여 드라이클리닝견뢰도는 KS K ISO 105 D01:2005법으로, Fade-o-meter를 이 용하여 일광견뢰도는 KS K ISO 105 B02:2005법으 로 측정하였다.

\section{Measurement of antibacterial properties}

공시균으로 Staphylococcus aureus(ATCC 6538) 와 Klebsiella pneumoniae(ATCC 4352)을 사용, $\mathrm{KS}$ K 0693: 2001에 의하여 정균감소율(bacteria reduction rate)을 측정, 항균성을 평가하였다.

\section{Results and Discussion}

\section{Effects of dyeing conditions}

〈Fig. 2〉는 $70^{\circ} \mathrm{C}, 100$ 분에서 염색 시 색소농도(10 $100 \% \mathrm{v} / \mathrm{v})$ 에 따른 염색성 $(\mathrm{K} / \mathrm{S}$ 값 $)$ 의 변화이다. 색소 농도의 증가에 따라 염색성은 증가하는 경향을 나 타냈으며, $90 \% \mathrm{v} / \mathrm{v}$ 이상의 농도에서는 증가 경향이

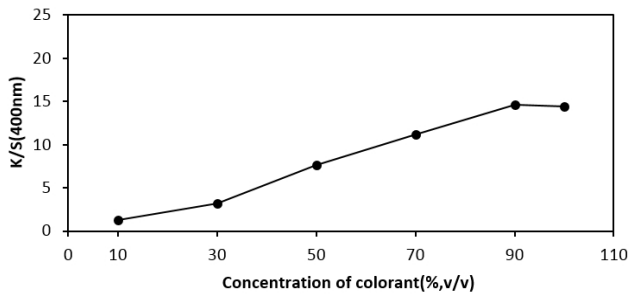

〈Fig. 2〉 Effect of colorant concentration on $\mathrm{K} / \mathrm{S}$ of fabrics dyed with Polygonum cuspidatum extract 
둔화하였다. 이와 같이 염색성은 호장근 추출 색소 농도가 증가할수록 증가하는 경향을 나타냈는데, 더 많은 색소들이 염욕에서의 색소농도가 증가할수록 시료직물로 이동하여 염착됨으로서 더욱 강한 색의 깊이가 되기 때문이라고 생각된다(Shin, Son, \& Yoo, 2008). 결과로부터 $90 \% \mathrm{v} / \mathrm{v}$ 가 적정 색소농도라 판단 되어진다.

〈Fig. 3〉은 $90 \% \mathrm{v} / \mathrm{v}$ 의 색소농도로 염색 시 염색 온도에 의한 염색성 변화를 나타낸 것이다. 염색 시 온도가 증가할수록 염색성은 증가하였으나, 염색온 도 $70^{\circ} \mathrm{C}$ 이상에서는 그 증가가 둔화하여 거의 평형 에 도달하는 경향을 나타냄을 알 수 있었다. 일반적 으로 염색온도가 상승하면 섬유의 분자간격이 넓어 지고, 색소 분자운동이 활발해져 염착량이 증가하게 되어 염색온도가 증가할수록 염색성은 증가하는 것 으로 판단되어진다(Sa, Choi, \& Lee, 2013). 그러나 본 실험결과에서 $70^{\circ} \mathrm{C}$ 이상의 염색온도에서는 거의 평형에 도달하는 경향을 나타내었는데, $70^{\circ} \mathrm{C}$ 이상 의 염색온도에서는 섬유 내부에 염착되는 색소의 양보다 섬유에 염착된 호장근 추출색소가 염액 속 으로 빠져나오는 양이 더 많기 때문에(Kim, 2004), 염색온도가 증가하더라도 뚜렷한 염색성의 증가는 없는 것으로 사료된다. 본 실험 조건에서 적정 염색 온도는 $70^{\circ} \mathrm{C}$ 라고 생각되어진다.

〈Fig. 4〉는 호장근 추출 색소농도 $90 \% \mathrm{v} / \mathrm{v}$ 로, $70^{\circ} \mathrm{C}$ 에서 염색 시 염색시간에 따른 염착량의 변화를 나 타낸 것이다. 염색 시 100 분까지 호장근 색소들의 흡착은 빨리 진행되어 염색성은 증가하였으며, 염색 시간 100 분에서 최대 염색성을 나타낸 후, 그 이상의 시간에서는 약간 감소하는 경향을 나타내었다. 이같 은 경향은 100 분까지는 색소의 음이온과 견섬유의

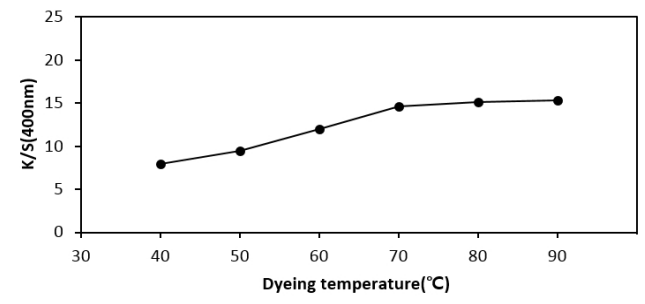

〈Fig. 3〉 Effect of dyeing temperature on $\mathrm{K} / \mathrm{S}$ of fabrics dyed with Polygonum cuspidatum extract

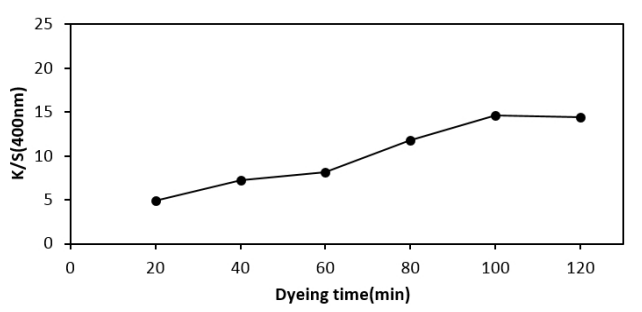

〈Fig. 4〉 Effect of dyeing time on $\mathrm{K} / \mathrm{S}$ of fabrics dyed with Polygonum cuspidatum extract

아민기 $\left(-\mathrm{NH}_{2}\right)$ 사이에서 이온 결합이 지속적으로 이루어 염색성이 증가하였으나, 그 이후에는 단분자 형의 흡착곡선 형태와 유사하게 염착량이 평형상태 에 도달하여 염색시간의 증가에 의한 염착량 $\mathrm{K} / \mathrm{S})$ 의 증가는 더 이상 나타내지 않는다고 생각되어진다( $\mathrm{Sa}$, Choi, \& Lee, 2013). 따라서 적정 염색시간은 100 분 이라고 판단되었다.

호장근 색소농도 $90 \% \mathrm{v} / \mathrm{v}$ 에서, $70^{\circ} \mathrm{C}$ 로 100 분간 염색 시 염색성에 미치는 $\mathrm{pH}$ 의 영향을 〈Fig. 5>에 보였다. 산성으로 염욕이 변함에 따라 염색성의 증 가 경향을 보였으며, 최대 염색성은 $\mathrm{pH} 3$ 에서 나타 났다. 일반적으로 견섬유 염색 시 염착량은 염욕의 $\mathrm{pH}$ 가 견섬유의 등전점 부근에서 높다고 알려져 있 는데(Choi \& Kim, 1998), 이는 견직물의 등전점(pH 3.8 4.0) 부근에서는 섬유표면에 안정성이 큰 양이 온의 양이 증가하기 때문으로 생각된다(Lee \& Jang, 2003). 호장근 추출액의 $\mathrm{pH}$ 는 4.95 5.10으로 산성욕 으로 염욕이 변함에 따라 염욕의 $\mathrm{pH}$ 로 인해 증가한 견직물 표면에 존재하는 양이온기(+)와 음이온기 $(-)$ 인 호장근 추출색소의 결합이 활발해져 염색성이 증가하는 것으로 판단되었다.

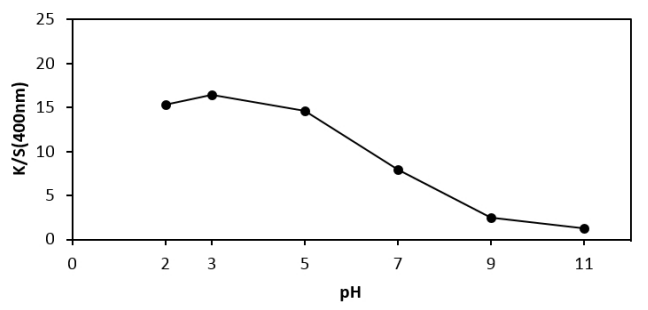

〈Fig. 5〉 Effect of $\mathrm{pH}$ on $\mathrm{K} / \mathrm{S}$ of fabrics dyed with Polygonum cuspidatum extract 
2. Effects of mordant conditions

$\mathrm{Al}, \mathrm{Cu}$ 및 $\mathrm{Fe}$ 매염제로 매염하였을 때 매염농도 및 매염방법에 따른 $\mathrm{K} / \mathrm{S}$ 의 변화를〈Fig. 6〉과〈Fig. 7〉에 나타내었다. 〈Fig. 6〉은 선매염한 견직물의 염 색성의 변화를 나타낸 것으로 $\mathrm{Cu}$ 및 $\mathrm{Fe}$ 를 이용하여 매염한 경우, 매염제 농도가 증가할수록 $\mathrm{K} / \mathrm{S}$ 값은 증 가하다가 매염제 농도 $3 \%$ 에서 최대 염색성을 보인 뒤 매염제 농도의 증가에 따라 $\mathrm{K} / \mathrm{S}$ 값은 저하하였으 며, $\mathrm{Al}$ 의 경우, 매염제 농도가 증가함에 따라 증가하 는 경향을 나타내어 $5 \%$ 에서 최대 염색성을 나타냈다.

〈Fig. 7〉은 후매염 시 $\mathrm{K} / \mathrm{S}$ 의 변화를 나타낸 것으 로 $\mathrm{Al}$ 매염의 경우, $2 \%$ 농도에서 높은 염색성을 보 인 뒤, 매염제 농도가 증가함에 따라 $\mathrm{K} / \mathrm{S}$ 값은 저하 하였다. $\mathrm{Cu}$ 의 경우, 매염제 농도가 증가함에 따라 염색성은 증가하여 최대 $\mathrm{K} / \mathrm{S}$ 값을 $2 \%$ 에서 나타낸 뒤, 그 이상의 매염제 농도에서 $\mathrm{K} / \mathrm{S}$ 값은 감소하는 경향을 나타내었으며, 매염제 $\mathrm{Fe}$ 의 경우 $1 \%$ 에서 최 대의 $\mathrm{K} / \mathrm{S}$ 값을 보인 뒤 매염농도가 증가함에 따라 염색성은 꾸준히 감소하였다.

〈Table 2〉는 선매염 후 염색한 시료 직물의 표면

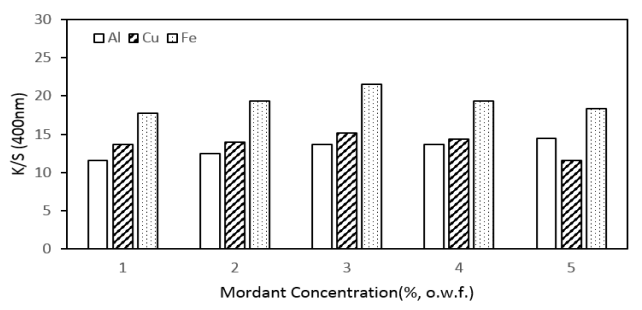

〈Fig. 6〉 Effects of mordant concentration on K/S value of fabrics dyed with Polygonum cuspidatum extract by pre-mordanting method

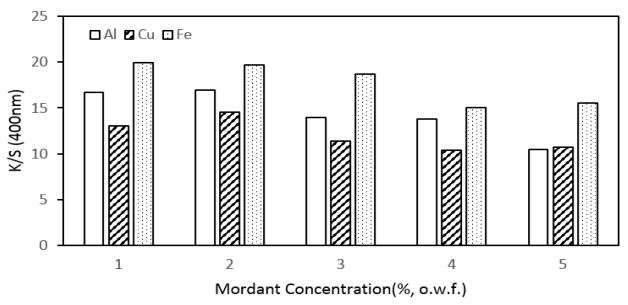

〈Fig. 7〉 Effects of mordant concentration on $\mathrm{K} / \mathrm{S}$ value of fabrics dyed with Polygonum cuspidatum extract by post-mordanting method

〈Table 2〉 Color values of fabrics dyed with Polygonum cuspidatum by pre-mordanting

\begin{tabular}{|c|c|c|c|c|c|c|}
\hline & & $\mathrm{L}^{*}$ & $a^{*}$ & $b^{*}$ & $\mathrm{H}$ & $\mathrm{V} / \mathrm{C}$ \\
\hline Unmordanted & & 64.54 & 9.64 & 59.93 & $2.31 \mathrm{Y}$ & $6.28 / 9.19$ \\
\hline Mordant & Concentration( $\%$,o.w.f. $)$ & & & & & \\
\hline \multirow{5}{*}{$\mathrm{Al}$} & 1 & 63.81 & 6.10 & 56.91 & $3.21 \mathrm{Y}$ & $6.21 / 8.50$ \\
\hline & 2 & 62.97 & 6.16 & 58.35 & $3.44 \mathrm{Y}$ & $6.13 / 8.74$ \\
\hline & 3 & 61.76 & 6.34 & 58.42 & $3.46 \mathrm{Y}$ & $6.01 / 8.73$ \\
\hline & 4 & 61.51 & 6.38 & 58.41 & $3.48 \mathrm{Y}$ & $5.94 / 8.77$ \\
\hline & 5 & 61.10 & 6.96 & 58.73 & $3.49 \mathrm{Y}$ & $5.93 / 8.79$ \\
\hline \multirow{5}{*}{$\mathrm{Cu}$} & 1 & 61.84 & 6.66 & 54.29 & $3.32 \mathrm{Y}$ & $6.01 / 8.69$ \\
\hline & 2 & 59.96 & 7.44 & 54.93 & $2.61 \mathrm{Y}$ & $5.68 / 8.26$ \\
\hline & 3 & 54.87 & 10.13 & 50.95 & $1.85 \mathrm{Y}$ & $5.32 / 7.92$ \\
\hline & 4 & 56.37 & 9.26 & 52.37 & $2.24 \mathrm{Y}$ & $5.47 / 8.05$ \\
\hline & 5 & 58.56 & 6.88 & 55.30 & $3.37 \mathrm{Y}$ & $5.73 / 8.21$ \\
\hline \multirow{5}{*}{$\mathrm{Fe}$} & 1 & 49.03 & 0.68 & 38.55 & $5.93 \mathrm{Y}$ & $4.75 / 6.70$ \\
\hline & 2 & 45.50 & 1.02 & 38.97 & $5.79 \mathrm{Y}$ & $4.41 / 5.75$ \\
\hline & 3 & 43.61 & 3.05 & 48.55 & $4.76 \mathrm{Y}$ & $4.23 / 5.47$ \\
\hline & 4 & 44.77 & 0.82 & 37.09 & $5.88 \mathrm{Y}$ & $4.25 / 5.50$ \\
\hline & 5 & 46.93 & 0.45 & 37.89 & $6.09 \mathrm{Y}$ & $4.26 / 5.64$ \\
\hline
\end{tabular}


색 변화로 명도의 경우, 무매염 염색한 견직물에 비 교하였을 때 매염 시 저하하였으며, $\mathrm{Fe}$ 매염제의 경 우가 가장 큰 폭으로 저하하였다. Fig. 6 의 결과에서 알 수 있듯이, 염착량의 증가에 의해 색상이 진하여 졌기 때문이라고 생각된다. $a^{*}$ 의 색감각지수 경우, 일반적으로 모든 매염제에서 무매염한 염색직물에 비하여 저하하여 매염에 의해 녹색기미가 증가하는 경향을 보였다. 또한 매염제 농도가 증가함에 따라 $\mathrm{Al}$ 매염하였을 때는 적색기미가 증가하는 경향을 나타내었으며, $\mathrm{Cu}$ 매염 및 $\mathrm{Fe}$ 의 경우에는 적색기미 가 증가하다가 녹색기미가 다시 증가함을 알 수 있 었다. $\mathrm{b}^{*}$ 의 경우, $\mathrm{Al}$ 매염한 직물은 무매염한 염색직 물에 비하여 큰 변화를 나타내지 않았으며, $\mathrm{Cu}$ 및 $\mathrm{Fe}$ 매염제의 경우 청색기미가 증가하는 경향을 나 타내었다. 색상은 무매염 시 $2.31 \mathrm{Y}$, 매염 시 $6.09 \mathrm{Y}$ $1.85 \mathrm{Y}$ 이었다.

〈Table 3〉은 후매염 시의 표면색 변화로 매염처 리에 의한 명도는 저하하는 경향을 나타내고, 색감 각지수 $\mathrm{a}^{*}$ 의 경우에서 $\mathrm{Al}$ 및 $\mathrm{Fe}$ 매염 시 녹색기미가 증가하였으나, $\mathrm{Cu}$ 로 매염하였을 때 적색기미가 강
해지는 결과를 보였다. $\mathrm{b}^{*}$ 의 경우에는 $\mathrm{Al}$ 매염 시 저농도에서 황색기미가 약간 증가하였으나, $\mathrm{Cu}$ 및 $\mathrm{Fe}$ 매염 시에는 청색기미가 강하여졌다. 색상은 $\mathrm{Al}$ 및 $\mathrm{Fe}$ 매염 시 $\mathrm{Y}$ 계열의 색상을, $\mathrm{Cu}$ 매염에서는 $\mathrm{YR}$ 계열의 색상을 나타내었으며, 무매염 염색직물과 비 교하여 채도는 감소하는 경향을 나타내었다.

〈Table 4〉는 무매염 염색견직물과 각종 매염제로 선매염 및 후매염한 최대 $\mathrm{K} / \mathrm{S}$ 를 나타내는 견직물의 표면색을 나타낸 것이다. 선매염시에는 무매염 염색 견직물과 같은 Yellow 계열의 색상을, 후매염의 경 우도 $\mathrm{Cu}$ 매염 시의 Yellow Red 계열을 제외하고는 동일한 색상을 보이고 있음을 알 수 있었으며, $\mathrm{Fe}$ 매염의 경우〈Table 2〉 및〈Table 3〉에서도 알 수 있 듯이 녹색을 띄는 경향이 증가하였음을 육안으로 확인하였다.

\section{Colorfastness property}

〈Table 5〉는 무매염한 염색직물과 매염제 농도 $5 \%$ 에서 $40^{\circ} \mathrm{C}$ 로 20 분 후매염한 매염 염색직물의 염 색견뢰도를 나타낸 결과이다.

〈Table 3〉 Color values of fabrics dyed with Polygonum cuspidatum by post-mordanting

\begin{tabular}{|c|c|c|c|c|c|c|}
\hline & & $\mathrm{L}^{*}$ & $a^{*}$ & $b^{*}$ & $\mathrm{H}$ & $\mathrm{V} / \mathrm{C}$ \\
\hline Unmordanted & & 64.54 & 9.64 & 59.93 & $2.31 \mathrm{Y}$ & $6.28 / 9.19$ \\
\hline Mordant & Concentration(\%,o.w.f.) & & & & & \\
\hline \multirow{5}{*}{$\mathrm{Al}$} & 1 & 60.86 & 7.14 & 60.14 & $3.24 \mathrm{Y}$ & $5.92 / 9.00$ \\
\hline & 2 & 59.46 & 7.28 & 60.71 & $3.17 \mathrm{Y}$ & $5.78 / 9.10$ \\
\hline & 3 & 61.98 & 6.58 & 59.26 & $3.39 \mathrm{Y}$ & $6.03 / 8.85$ \\
\hline & 4 & 62.69 & 6.20 & 59.01 & $3.52 \mathrm{Y}$ & $6.10 / 8.86$ \\
\hline & 5 & 63.65 & 4.50 & 56.21 & $4.02 \mathrm{Y}$ & $6.19 / 8.29$ \\
\hline \multirow{5}{*}{$\mathrm{Cu}$} & 1 & 40.36 & 24.05 & 39.03 & 4.63YR & $4.01 / 7.83$ \\
\hline & 2 & 39.18 & 23.13 & 39.54 & 5.54YR & $3.80 / 7.99$ \\
\hline & 3 & 43.03 & 25.10 & 32.90 & 4.11YR & $4.33 / 7.22$ \\
\hline & 4 & 45.24 & 25.26 & 26.38 & $2.78 \mathrm{YR}$ & $4.17 / 6.44$ \\
\hline & 5 & 46.36 & 24.99 & 27.29 & $2.67 \mathrm{YR}$ & 4.11/6.59 \\
\hline \multirow{5}{*}{$\mathrm{Fe}$} & 1 & 37.87 & -1.48 & 31.50 & $7.47 \mathrm{Y}$ & $3.68 / 4.01$ \\
\hline & 2 & 39.03 & -1.80 & 30.37 & $7.78 \mathrm{Y}$ & $3.79 / 4.33$ \\
\hline & 3 & 39.22 & -1.97 & 29.66 & $7.88 \mathrm{Y}$ & $3.81 / 4.45$ \\
\hline & 4 & 40.81 & -2.13 & 27.57 & $7.95 \mathrm{Y}$ & $4.15 / 4.65$ \\
\hline & 5 & 42.80 & -2.23 & 26.62 & $8.19 \mathrm{Y}$ & $4.31 / 4.56$ \\
\hline
\end{tabular}


〈Table 4〉 Color of fabrics dyed with various mordanting method and mordant

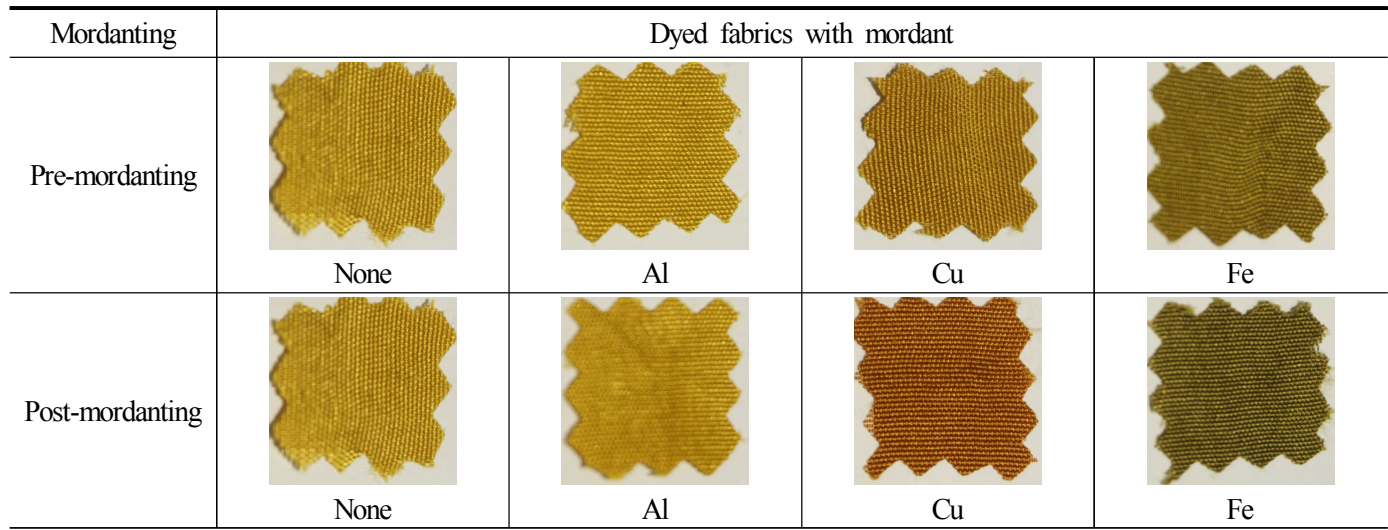

〈Table 5〉 Colorfastness of fabrics dyed with Polygonum cuspidatum and mordanted with mordant

\begin{tabular}{|c|c|c|c|c|c|c|c|}
\hline Colorfastness & & & & Unmordanted & $\mathrm{Al}$ & $\mathrm{Cu}$ & $\mathrm{Fe}$ \\
\hline Light & & & & 1 & 2 & 3 & $2-3$ \\
\hline Dry cleaning & & & & 4 & $4-5$ & $4-5$ & $4-5$ \\
\hline \multirow{3}{*}{ Washing } & & Fade & & 1 & $1-2$ & 2 & 2 \\
\hline & & Satin & Cotton & $3-4$ & $3-4$ & $3-4$ & $3-4$ \\
\hline & & & Silk & $2-3$ & $2-3$ & 3 & $2-3$ \\
\hline \multirow{2}{*}{ Rubbing } & Dry & & & $4-5$ & $4-5$ & $4-5$ & $4-5$ \\
\hline & Wet & & & 4 & $4-5$ & $4-5$ & $4-5$ \\
\hline \multirow{6}{*}{ Perspiration } & \multirow{3}{*}{ Acidic } & Fade & & 2 & 4 & 4 & 4 \\
\hline & & Satin & Cotton & $4-5$ & $4-5$ & $4-5$ & $4-5$ \\
\hline & & & Silk & $4-5$ & $4-5$ & $4-5$ & $4-5$ \\
\hline & \multirow{3}{*}{ Alkaline } & Fade & & 2 & 4 & 2 & $3-4$ \\
\hline & & Satin & Cotton & $4-5$ & $4-5$ & $4-5$ & $4-5$ \\
\hline & & & Silk & $4-5$ & $4-5$ & $4-5$ & $4-5$ \\
\hline
\end{tabular}

무매염 염색직물에 비해 매염 염색직물은 일광견 뢰도의 증가를 나타내어 1 2등급 향상되었다. 드라 이클리닝견뢰도는 무매염 및 매염의 경우 모두 4 5 급의 우수한 견뢰도를 나타내었으며, 세탁견뢰도는 변퇴색에 있어 무매염 염색견직물의 경우 1 급으로 낮았으나, 후매염 염색견직물은 견뢰도의 증가를 나 타내어 1등급 향상되었으며, 오염은 2 3급 및 3 4 급의 견뢰도를 보였다. 마찰견뢰도는 건습 모두에서 4 5급이었으며, 땀견뢰도의 경우 무매염 염색견직 물의 경우 2급으로 낮았으나, 변퇴색에 있어서 산성 땀액의 경우 매염에 의해 견뢰도는 증가하는 경향
을 나타내었으며, 알칼리 땀액의 경우 $\mathrm{Al}$ 매염 시 4 급으로 뚜렷한 견뢰도의 향상을 나타내었다. 오염에 있어서는 거의 4 5급의 우수한 견뢰도를 보여 매염 으로 인한 견뢰도의 향상을 보였다.

\section{Antibacterial property}

〈Table 6〉은 황색포도상구균(Staphylococcus aureus) 과 폐렴간균(Klebsiella pneunmoniae)을 사용하여 평 가한 항균효과를 나타낸 것이다. 황색포도상구균의 경우, 염색한 직물은 $90.6 \%$ 의 균감소율을 나타내었 으며, 매염 및 염색한 직물은 99.9 97.1\%의 정균감 
〈Table 6〉 Antibacterial activity of fabrics dyed with Polygonum cuspidatum and mordanted with mordant

\begin{tabular}{l|c|c}
\hline \multirow{2}{*}{$\begin{array}{r}\text { Antibacterial } \\
\text { Fabrics }\end{array}$} & \multicolumn{2}{|c}{ Bacteria reduction rate(\%) } \\
\cline { 2 - 3 } & $\begin{array}{c}\text { Staphylococcus } \\
\text { aureus }\end{array}$ & $\begin{array}{c}\text { Klebsiella } \\
\text { pneumoniae }\end{array}$ \\
\hline Untreated & 46.4 & 42.0 \\
\hline Dyed & 90.6 & 89.2 \\
\hline Al mordanted & 97.1 & 90.5 \\
\hline Cu mordanted & 99.9 & 99.9 \\
\hline Fe mordanted & 99.7 & 91.6 \\
\hline
\end{tabular}

소율을 보였다. 폐렴간균의 경우, 균감소율이 무염 색견직물의 경우 $89.2 \%, \mathrm{Al}$ 및 $\mathrm{Cu}$ 매염의 경우 각각 $90.5 \%$ 및 $91.6 \%$ 이었으며, $\mathrm{Cu}$ 매염 시 $99.9 \%$ 의 정균 감소율을 나타내 폐렴간균에 대한 뚜렷한 항균효과 를 보였는데, 이는 $\mathrm{Cu}$ 자체가 가지는 항균성에 기인 한 것으로 사료되었다.

\section{Conclusion}

호장근에서 추출한 색소를 이용하여 견직물에 염 색할 때 염색조건에 따른 염색성, 매염시의 표면색 변화, 각종 견뢰도 및 항균성을 분석한 결과는 다음 과 같은 결론을 얻었다.

1. 적정 염색조건은 색소농도 $90 \% \mathrm{v} / \mathrm{v}$, 염색온도 $70^{\circ} \mathrm{C}$, 염색시간 100 분이었으며, $\mathrm{pH}$ 가 알칼리성일 때 염색성은 매우 낮았으며, 산성욕에서 염착량은 증가 하는 경향을 나타내어 최대 염착량을 $\mathrm{pH} 3$ 에서 나 타내었다.

2. 매염했을 때 염색성은 선매염 시 $\mathrm{Al}, \mathrm{Cu}, \mathrm{Fe}$ 순 으로, 후매염 시 $\mathrm{Cu}, \mathrm{Al}, \mathrm{Fe}$ 순으로 증가하였다. 선 매염시 $\mathrm{Al}$ 의 경우, 매염농도 $5 \%$ (o.w.f)에서, $\mathrm{Cu}$ 및 $\mathrm{Fe}$ 의 경우는 최대 $\mathrm{K} / \mathrm{S}$ 값을 $3 \%$ 에서 나타냈다. 후매 염하였을 때 각각 $2 \%, 2 \%$ 및 $1 \%$ 에서 최대 $\mathrm{K} / \mathrm{S}$ 값을 나타냈으나, 환경측면에서 고려했을 때 적정 매염제 농도는 1 3\%(o.w.f)를 사용하여도 염색성에 큰 차 이는 나타나지 않을 것으로 사료된다.

3. 표면색의 변화에서 매염처리 시 명도는 일반 적으로 저하하는 경향을 보였으며, 선매염의 경우 무매염에 비해 일반적으로 녹색기미와 청색기미가 증가하였다. 후매염의 경우에는 $\mathrm{Cu}$ 매염 시 뚜렷한
적색기미와 청색기미의 증가를, $\mathrm{Fe}$ 매염의 경우 녹 색기미와 청색기미의 증가를 나타내었다. 매염처리 에 의해 일반적으로 채도는 저하하는 경향을 보였 으며, 매염제 농도에 의해 표면색상은 $8.19 \mathrm{Y} \sim 1.85 \mathrm{Y}$ 계열 및 5.54YR 2.67YR 계열을 보였다.

4. 매염에 의해 일반적으로 각종 견뢰도들은 향상 되었으며, 염색견직물은 황색포도상구균에 대해 $90.6 \%$, 염색 후 매염 처리한 견직물은 $97.1 \%$ 이상의 정균 감소율을 보이고, 폐렴간균에 대해서는 매염 처리 시에 $90.5 \%, \mathrm{Cu}$ 매염 시 $99.9 \%$ 의 정균감소율을 나 타내었다.

본 연구 결과로부터 호장근 추출색소는 염색조건 및 매염조건에 따라 Yellow 및 Yellow Red 계열의 색상을 나타내며, 다양한 채도의 색상을 발현하는 것으로 확인되었으며, 패션소재 제조용 천연염료로 서의 사용 가능성을 확인할 수 있었다. 패션의류제 품 제작용 직물염색에의 보다 폭 넓은 활용을 위하 여 소취성, 자외선 차단특성 등과 같은 기능성 검토 와 염색견뢰도(일광견뢰도 및 세탁견뢰도)의 향상 을 위한 후속연구가 이어져야 하겠다.

\section{References}

Chang, J. S., Liu, H. W., Wang, K. C., Chen, M. C., Chiang, L. C., Hua, Y. C., \& Lin, C. C. (2005). Ethanol extract of Polygonum cuspidatum inhibits hepatitis B virus in a stable HBV-producing cell line. Antiviral Research, 66(1), 29-34. doi:10.1016/ j.antiviral.2004.12.006

Choi, S. C., \& Jung, J. S. (1997). Studies of antimicrobial from extracts of impatiens balsamina (I). Journal of the Korean Fiber Society, 34(6), 393399.

Choi, S. C., \& Kim, M. S. (1998). Studies on the dyeing properties of silk and cotton fabrics with alnus firma fruit extract. Journal of the Korean Fiber Society, 35(3), 161-173.

Choi, S. H., \& Cho, Y. S. (2001). Dyeing of natural fibers with extract of ginkgo biloba bark (II): Fastness and functional characteristics of dyed fabrics. Textile Coloration and Finishing, 13(6), 
$1-8$.

Han, M. H. (2000). The dyeability and antibacterial • deodorization activity of silk fabrics by gromwell extracts. Textile Coloration and Finishing, 12(5), 29-35.

Hong, B. S., Chu, Y. J., \& Lee. E. J. (2010). Natural dyeing absorption properties of chitosan and nano silver composite non-woven fabrics: Focus on Chrysanthemum indicum Linn. Journal of the Korean Society of Clothing and Textiles, 34(5), 775-783. doi:10.5850/JKSCT.2010.34.5.775

Hsu, C. Y., Chan, Y. P., \& Chang, J. (2007). Antioxidant activity of extract from Polygonum cuspidatum. Biological Research, 40(1), 13-21. doi:10. 4067/S0716-97602007000100002

Jung, H. A., Roh, S. S., \& Oh, M. S. (2009). The effects of Polygonum cuspidatum on the skin functions. Journal of Oriental Rehabilitation Medicine, 19(1), 73-89.

Kim, A. S. (2004). A study on the chemical and dyeing properties of Rhus verniciflua extract. Textile Coloration and Finishing, 16(6), 16-22.

Kim, K. W., Ha, K. T., Park, C. S., Jin, U. H., Chang, H. W., Lee, I. S., \& Kim, C. H. (2007). Polygonum cuspidatum, compared with baicalin and berberine, inhibits inducible nitric oxide synthase and cyclooxygenase-2 gene expressions in RAW 264.7 macrophages. Vascular Pharmacology, 47(2/3), 99-107. doi:10.1016/j.vph.2007.04.007

Kim, M. S., \& Choi, S. C. (2001a). The dyeing properties of Polygonum cuspidatum extract (I). Textile Coloration and Finishing, 13(1), 45 - 54.

Kim, M. S., \& Choi, S. C. (2001b). The dyeing properties of Korean knotweed extract (II): The UV-visible spectrophotometric characteristics of Korean knotweed extracts. Textile Coloration and Finishing, 13(5), 10-17.

Kim, M. S., Choi, S. C., \& Cho, K. R. (2002). The dyeing properties of Korean knotweed extract (III): Light Fastness. Textile Coloration and Finishing, 14(1), 34-42.
Kim, T. J. (1996). Korean resources plants. Seoul: Seoul National University.

Kim, Y. S., Kim, H. H., Yoo, M. J., \& Shin, D. H. (2004). Bactericidal effect of the extracts of Polygonum cuspidatum on Bacillus cereus. Food Science and Biotechnology, 13(4), 430-433.

Lee, C. B. (1980). Illustrated encyclopedia of flora of Korea. Seoul: Hyangmunsa.

Lee, Y. S., \& Jang, J. D. (2003). The dyeing properties of silk fabric of leaf mustard (Brassica juncea) extract. Fashion \& Textile Research Journal, 5(4), 389-394.

Lee, Y. S., \& Jang, J. D. (2010). Dyeing and functional property of cotton fabrics dyed with Glycyrrhizae Radix extract (I): The color depth of cotton fabrics by mercerization $\&$ tannic acid treatment. Fashion \& Textile Research Journal, 12(4), 523-530. doi: 10.5805/KSCI.2010.12.4.523

Park, Y. H. (2006). The dyeability and antibacterial activity of fabrics dyed with lavender extract. Journal of the Korean Society of Costume, 56(1), 97-105.

Park, Y. H. (2007). A study on the dyeability and antibiosis of fabrics dyed with Solanum nigrum extract. Journal of the Korean Society of Costume, 57(4), 61-69.

Ryuk, C. S. (1997). 생약도감: 아세아 [llustrated Encyclopedia of Medical Plants of Asia]. Seoul: Kyungwon.

Sa, A. N., Choi, H. J., \& Lee, J. S. (2013). Dyeing properties and functionalities of Alnus japonica bark and heartwood extracts. Textile Science and Engineering, 50(5), 283-291. doi:10.12772/TSE. 2013.50.283

Shin, Y. S., Son, K. H., \& Yoo, D. I. (2008). Dyeing properties and color of silk fabrics dyed with safflower yellow dye. Journal of the Korean Society of Clothing and Textiles, 32(6), 928-934. doi:10. 5850/JKSCT.2008.32.6.928

Son, W. K., \& Shin, J. S. (2006). Dyeability using characteristics of curly dock. The Research Journal 
of the Coustume Culture, 14(2), 260-270.

Yi, E. J., Yoo, E. S., Han, C. H., \& Lee, A. R. (2010). Dyeing properties and color characteristics of silk fabrics dyed with Prunus yedoensis Matsumura flower extract. Textile Coloration and Finishing, 22(3), 194-206. doi:10.5764/TCF.2010.22.3.194 